After tea and a tour of the Institute, the Lecture Hall was filled for a delightful inaugural address by Professor Woods on "Experimental Studies on the Pathogenesis and Therapy of Ocular Tuberculosis"; this will be published in a future issue of this journal. In the evening an enjoyable dinner was held at Claridge's Hotel, at which Professors Weve and Woods proposed the toast of the Institute, and Sir Stewart Duke-Elder replied.

\title{
CORRESPONDENCE
}

\section{APOLOGIA PRO VITA MEA}

\section{To the Editorial Committee of}

THE BRITish Journal OF Ophthalmology

DEAR SIRS,-On giving up the post of senior editor I wish to thank all my colleagues on the Editorial Board for their forbearance and the great kindness shown to me for so many years. And I should also like to thank those subscribers who have from time to time written me appreciative letters. To know that I had the good will of the fraternity has been a great help. It might be thought that an editor's life comes within Mr. Mantalini's definition "one demd horrid grind," but I have not found this to be the case and my journal years have been very happy ones indeed.

Sir William Usler once wrote something to the effect that it was wonderful how a bad boy may fool his fellows if he once gets to work. I believe my only editorial assets have been two in number: first, writing has always come easily to me, and in saying this I hope that I have not been unmindful of the dictum of Edward Fitzgerald, that "easy writing often makes for difficult reading": secondly, I was early in life introduced to good English literature. In connexion with my first point I recall one of my prep. school reports in which my essays in divinity were commended, the master adding "he has a good fund of English on which to draw." Perhaps any facilities I may have shown in the concoction of annotations may be traced to this early source. With regard to my second point, the same master who praised my English essays (the less said about my efforts in Latin the better) was wont to read aloud to those of us who cared to listen, and in this way introduced me to Pickwick and The Rose and the Ring. My father also used to read out to us in the holidays and he took me through most of the Waverley Novels. Scott, Dickens and Thackeray are good foundations in English literature. And a parson's son who has to attend church twice a 
Sunday, clad as Hood clothed the Devil, that is to say in his Sunday best, must be a hopeless ass if he does not learn in time to appreciate the extraordinary beauty of much of the prose of the Book of Common Prayer.

It might be thought that with my early theological leanings I should have done better to enter the Church, especially as a family living was, and is, situated among the hills of South Shropshire. But I had the gravest doubts as to my ability ever to become what one of the bidding prayers calls a discreet Minister of God's word. I felt, too, that I could never fill the pulpit from which my maternal grandfather had thundered at the rude forefathers of the hamlet who slept in the box pews beneath. The Rectory was a mile from the church, high up on the hill side, facing due east, and bitterly cold in winter.

I have never regretted that I chose the medical rather than the clerical profession. My choice of medicine was fortuitous, and was due to the Gloucester smallpox epidemic of 1896. My home was nowhere near Gloucester, but my father decided that the household should be vaccinated. As I was being done, it suddenly struck me that it didn't seem to be particularly difficult, and that here was a career in which the fool of the family might make good. My enthusiasm, however, received a couple of shocks before I left school. The first came from a schoolfellow, himself the son of a doctor, who asked me what I was to do in after life, and when I said I hoped to be a doctor, replied " do" you think you have enough brains to pass the examinations"? The second shock was delivered by my housemaster, who, when I asked him if he thought I could matriculate at the University of London, said " my dear boy, it's no use, you simply haven't the brains." I must confess that on my school record they were both abundantly right, and only hope that my subsequent career has done something to correct the verdict.

When I joined the staff of the British Journal of Ophthalmology I had already had some practice in correcting proofs with E. E. Henderson. I had my consulting room in his house during the time that he was editing the Ophthalmic Review. We neither of us had much practice, and he would occasionally give me a spare set of proofs to correct, and go through them with me afterwards. I owe him a great deal, for he taught me much. Among other things, I learned to beware of the split infinitive, sentences ending with prepositions and those starting with a past participle. Tautology, journalese and slang were all anathema to him.

As soon as I joined the Journal I found I could always take my difficulties to Sir Tohn Parsons and be sure of getting sound advice. I must have made myself a proper nuisance to him, to use an East Anglian expression; but he never seemed to mind, and I soon felt 
that if he were satisfied naught else mattered. We all know how much he has done for British Ophthalmology, but only the editorial staff know fully what he has been to the Journal.'

I am proud of having worked with him for the Journal, and would like to express my gratitude to him for his exceeding great goodness to me over a period of more than forty years.

In saying goodbye, I wish the Journal many years of prosperity and usefulness, and hope that those who work under the new arrangements will enjoy it as much as $I$ have done in the past.

Yours faithfully,

R. R. JAMES.

WOODBRIDGE.

To R. R. J.

\section{To the Editorial Committee of}

The BRITISH JOURNÁl, OF OPHThalmology.

DEAR SIRS,-It is with very genuine admiration and honour mingled with sadness that I salute my Editorial Chief, Mr. Rutson James, as he passes to well-deserved retirement. Like many famous men and women in our island history he comes from a large family brought up in a country parsonage, and belongs to a generation nurtured in that age of character and grace during the reign of Queen Victoria. The stock from which he comes, the background of his childhood and his training at Winchester, where "Manners makyth man". combined to make him a perfect example of the English gentleman. His courtesy to me through more than 19 years of happy association with him on the staff of the British Journal of Ophthalmology, and indeed to everyone he has dealt with, has been constant; and his sense of duty and rightness of the highest order. At times I have felt that he has been too lenient in handling my editorial misdeeds and shortcomings on occasions when I deserved stern rebuke. True to his character he would always take the full blame, and endure the discomfort of mind that went with this, for any fault : committed by a subordinate, and this, for a nature as acutely sensitive as his, is a tribute to his courage and loyalty.

- In this changing world men of his calibre and integrity are becoming rarer in all walks of life, and so we appreciate and value them the more. I could not have had a better chief, a wiser counsellor to whom to appeal for advice, or a more loyal friend. I owe him an immense debt for all he has taught me from his wide experience in literary matters, for the enjoyment of his whimsical humour, and for his high example of truth and honesty in writing and in all his dealings.

Yours faithfully,

H. B. StallaRd.

81, HARLEY STREET, w.1. 